\title{
TESTING THE VALIDITY OF THE BROWN-POTOSKI MODEL IN THE CZECH AND SLOVAK REPUBLICS
}

\author{
Jan Pavel, Emilia Sičáková-Beblavá*
}

\begin{abstract}
:
This paper is based on the new institutional economic approach, which focuses on analysis between services features (asset specificity, outcome measurability) and their eligibility to contract out. This issue, which de facto constitutes one of the subsets of the "make or buy decision" issue, is also analysed by the so-called Brown-Potoski model. It analyses the relations between selected features of a demanded service and its suitability or unsuitability for outsourcing, whilst making use of information about transaction costs economy.

Using data from 100 Czech municipalities and 100 Slovak municipalities, the viability of the Brown-Potoski model is tested. The results of the research show that a connection was identified between the measurability of the required service and its suitability for external provision, but the relationship between the specificity of investments and the suitability for external provision was not. The reason is probably the previous financial demands of the initial investment, which is, above all in the case of small municipalities, beyond their budgetary means.
\end{abstract}

Keywords: Brown-Potoski model, Czech Republic, public services, Slovak Republic, transaction costs

JEL Classification: D23, H42, H72

\section{Introduction}

After the fall of the Communist regime in 1989, extensive institutional and economic changes in the Central European countries took place, which lead, among other things, to the establishment of the system of municipality-based local self-government. Both in the Czech and Slovak Republics, the local government's sub-sector presently manages considerable amounts of public funds ${ }^{1}$ and uses a part of them for the provision of services for its citizens.

In the course of the political transition, the Slovak and Czech Republic decentralised the provision of various services, many of which are now decided by local self-government. Municipalities have the power to decide which service will be provided (apart from those which are stipulated by law) and the manner of their

* Jan Pavel, University of Economics, Prague (pavelj@vse.cz); Emilia Sičáková-Beblavá, Comenius University, Bratislava (ema@transparency.sk).

1 In 2006, the expenditure of municipal budgets in the Czech Republic constituted $7.7 \%$ of GDP; in Slovakia it was by 2 percentage points less, i.e. $5.7 \%$ of GDP. 
provision. From the viewpoint of an effective allocation of funds, it would be appropriate if economic criteria or the criteria of the $3 \mathrm{E}$ concept were decisive in choosing the manner of provision for individual services (Ochrana, 2003). At that, it must be emphasised that some services are suitable for outsourcing, whilst others are not (O'Looney, 1998). This issue, which de facto constitutes one of the subsets of the "make or buy decision" issue, is also analysed by the so-called Brown-Potoski model (Brown, Potoski, 2002). This examines the relationship between selected features of a demanded service and its suitability or unsuitability for outsourcing, whilst using information about the transaction costs economy. Testing of this model's application in the conditions of the Czech and Slovak Republic constitutes a subject of this article.

\section{Theoretical Aspects of the Provision of Services at Municipal Level}

When securing services, a municipal self-government must take many decisions. One of the main decisions is selecting the way of the service provision. This is generally deciding between the internal or external provision of services (Domberger, Rimmer, 1994). Here, it must be considered whether it is more profitable for the public sector to provide the given service within its direct competence or leave the service's provision to other entities in return for a certain reward (either explicit, in the form of regular payments from public budgets, or implicit, in the form of a provision to authorise the collection of certain fees from the public). Local self-government makes decisions on the way of the services' provision, which can be formulated, according to a general economic theory, as make or buy. This is a typical decision-making "make or buy" issue also faced by each private entity (Williamson, 1981).

From the viewpoint of the present main-stream economy, the use of an external provider is justified only if it increases the effectiveness of public funds (Medved' et al., 2005). This can be expressed as a proportion between the contributions and costs of a given service, where contributions could also be considered as benefits to the service user (Ochrana, 2007). If the selection of external production thus leads to a reduction of costs and at the same time, the overall contribution will not be decreased (e.g. due to a decreased quality), such a solution is most effective (Savas, 1987).

If we assume that a change in the production process will not lead to any change in the quality of the service provided, the question of selection of the service provider turns into an effort to minimize costs. The original neoclassical view presented e.g. in Cullis, Jones (1987) focuses only on production costs. If an offer of an external supplier is thus lower than the costs of direct production, it is economical to outsource the provision of the given service. However, such an approach is shown to be too narrow, because it does not take into account the consequences of a change in the management structure. By selecting an external supplier, the purchaser looses the possibility to quickly and cheaply influence the form of the provided services (Audit Commission, 1995). Negotiations with the supplier concerning any changes bring along additional costs, whose neglect leads to inappropriate decisions from the viewpoint of the neoclassical concept (Kerr, Radford, 1995).

The issue of the origination of additional costs in the performance of external contracts is dealt with by authors whom we can place in a theoretical movement 
of the transaction costs economy (Bajari, Tadelis, 2001). This emphasises that in the decision-making on the way of service provision, transaction costs should also be considered, alongside traditional production costs. It emphasises the need to monitor not only the production effectiveness, but also the amount of transaction costs relating to the given form of service provision. This is because in some cases, transaction costs can exceed savings from production costs achieved though contracting (Nemec, 2002). By contracting out, production costs of the provided service can be lowered. However, it is possible that the purchaser will eventually pay, both directly and indirectly, more than he/she paid for the internal provision of the given service.

Transaction costs originate both during internal and external service provision. Transaction costs can be related to both the economic and political characteristics of service provision. In the following part, we will focus on the economic context of the origination of transaction costs.

In both cases of service provision, a municipality, as the principal actor (the one, on whose behalf actions are taken) secures services through their provision by agents by its own employees or by other organisations. In both cases, contracts are incomplete and in both cases, information asymmetries between the principal and the agents can occur. However, there are other mechanisms affecting the amount of transaction costs for solving relations between the municipality and its agents - i.e. employees who are under its direct control, as well as relations between the municipality and the supplier (agent), which is not under its control. ${ }^{2}$ The transaction costs economy seeks an answer to the question where transaction costs are connected with individual alternatives. A precise definition of these costs has still not been set. With regard to the subject-matter of examination, transaction costs can be defined as management costs related either to the internal provision of services or to the service's purchase and securing through contracting. According to Williamson (1981), transaction costs are the "costs of planning, adjusting and monitoring of a task's fulfilment within individual alternatives of managing structures". In this context, we will help ourselves in defining transaction costs also with Pavel's definition (2005), who defined transaction costs as any costs related to the performance of a given contract outside production costs. Without spending these costs, the given transaction would never be carried out.

According to Sičáková-Beblavá, Beblavý (2007), we can talk about ex-ante and ex-post transaction costs. Ex-ante transaction costs include the drafting of a contract, contract negotiation and the creation of the conditions for securing the performance and observance of the contract, or agreement. There follows that contracts are seen to be incomplete, so it is not possible to solve in advance all possible ambiguities that will occur during service provision. Transaction costs originate also due to the low administrative capacity of a municipality, which must decide on issues related to securing service provision. Since the problem of low administrative capacity exists mainly in small municipalities, it can be generally observed that due to insufficient administrative demand, the amount of transaction costs is reversely proportionate to the municipality's size.

As we have already stated, individual contracting parties (in our case the municipality and the supplier) cannot specify precisely all possible situations that can

2 For more details concerning this issue see e.g. Williamson (1991). 
arise during a contract. Under such circumstances, the municipality faces a risk of the supplier's opportunistic behaviour, whether with respect to the quality or the price of the provided service. In the case of information asymmetry, when the supplier has more information about activities and efficiency than the municipality, the supplier can provide inaccurate information about its actions, fulfilment of determined and agreed tasks or activities. If the risk of opportunism is high, the municipality must pay more attention to post-contracting monitoring.

According to Brown, Potoski (2003), who used the transaction costs theory when examining decisions related to the organisation of the service provision, municipalities choose production mechanisms partially in order to minimise the risks relating to the securing of services. According to them, the risk is connected to the type of the service secured, i.e. to its features, rather than to the nature of the given service market and to the possible discrepancy between the municipality's and suppliers aims.

As for the service characteristics, which are related to the transaction costs, Williamson (1981) focuses on the specificity of the assets necessary for the provision of the respective service, the measurability of services and the frequency of ordering. This analysis will focus on the first two features.

What is necessary for service provision, first of all, are the employees, i.e. human resources. Following this, technical equipment by which the service is provided is necessary and last but not least, the service can have certain features, which define the terms of its provision. Asset specificity examines to what extent fixed investments (human resources, capital investments, etc.) are needed for the provision of a service. By fixed investments, we mean investments necessary for the provision of a service whose use for another type of service is more complicated. In the case of these investments, there is a risk of origination of sunk costs. For example, refuse collection vehicles are necessary for the collection of waste. Can they be used for other purposes, as well? The possibility of their transformation for another purpose is thus important. It follows that the more specific investment made by an investor, the more exceptional his status is in the given area and the more it inclines to have a monopolistic position. This can bring along a strengthening of his negotiation position, which increases the costs of achieving an agreement in the case of an incomplete contract, which can thus constitute several negatives.

Measurability of the provided service means to what extent it is possible to measure whether the given service is provided, and in what extent and quality it is provided. In the case of some services, it is difficult to measure them, for example the care of the mentally-ill, while other services are easier to measure (such as waste collection). Easily measurable services often have identifiable performance parameters that precisely express the quality and quantity of the service. Services can be measurable even in cases when it is not easy to define performance parameters, provided that the activities necessary for the service's provision can be monitored relatively easily. Measurability of a service is considered difficult neither if the results to be achieved, nor the activities to be performed are easily identifiable. Under such circumstances, the municipality faces a risk of insufficient performance and neglect in both cases - at outsourcing, as well as within internal service provision. However, with regard to the contract's character - an incomplete order for service provision concluded for a certain time period - the municipality does not have direct control of service provision and 
the related solving of any problems, and thus at contracting, it risks higher transaction costs, i.e. higher risk of insufficient performance and neglect ${ }^{3}$, unless contractual terms are well regulated.

There can be generally identified a reversely proportionate relationship between measurability of output and the amount of transaction costs, which appear in this case mostly in the form of monitoring costs. An implication of the above assertion is that contracting is more effective and appears more in the case of services, whose quality and quantity can be easily and precisely measured. If their measuring gets more difficult, the risk of an unclear contract and the possibility of the supplier's opportunistic behaviour is increasing. If the measuring of a service is extremely difficult, i.e. if the contract's outputs are not measurable and the municipality cannot monitor the activities, the municipality will most probably provide the service internally.

Brown, Potoski (2002) modify the main bases of the Williamson's (1981) concept and analyse the services provided by the public sector from the viewpoint of their suitability for external provision. As criteria, they use the specificity of investment and measurability of output. According to the two above criteria, they divide services provided by the public sector into four groups (see the Table 1).

The first case (A) concerns services, for which low specificity of investments and simple measuring of outputs is typical. The first factor allows an easy entering into the sector, thus increases competitive pressure and simultaneously decreases the possibility of a supplier's opportunistic behaviour. Easy measuring of outputs makes little demand on monitoring. Moreover, the costs related to negotiations concerning the form of output from the contract are unnecessary. The total transaction costs are thus low.

The second group of services (B) includes services with an easily measurable output. However, their provision is connected with high asset specificity (fixed investments). This concerns, above all, areas with high fixed costs, often network industries, where economies of scale can be made. Provision of this type of service is usually financially demanding at production of the first unit, considering high fixed costs. With continued production, there occurs cost savings, so the marginal costs are low. In this case, transaction costs of the monitoring of output are low thanks to an easy measuring. However, the high specificity of assets leads to considerable barriers in entering into a given sector and the origination of the provider's monopolistic position, with all potential negatives resulting from that.

The next group (C) includes services that are typical for low asset specificity and thus sufficient competitive incentives. However, it is difficult to measure output in this case, as transaction costs are generated by the necessity to prepare certain indicators necessary for the at least partial expression of output and its monitoring. The last group (D) includes services with high asset specificity whose outputs are difficult to be measured; transaction costs then reach the highest levels.

3 However, apart from municipalities, in some cases, monitoring of services can be done through a centrally defined regulation. 
Table 1

Division of Public Services according to the Specificity of Investments/Assets and Measurability of Output

\begin{tabular}{|l|l|l|}
\hline $\begin{array}{l}\text { Specificity } \\
\text { of of } \begin{array}{l}\text { Low } \\
\text { of output }\end{array}\end{array}$ & High \\
\hline Easy & $\begin{array}{l}\text { (A) Measurable market } \\
\text { services } \\
\text { TrC: }+\end{array}$ & $\begin{array}{l}\text { (B) Measurable monopolistic services } \\
\text { TrC: }++\end{array}$ \\
\hline Difficult & $\begin{array}{l}\text { (C) Non-measurable market } \\
\text { services } \\
\text { TrC: }++\end{array}$ & $\begin{array}{l}\text { (D) Non-measurable monopolistic } \\
\text { services } \\
\text { TrC: }+++\end{array}$ \\
\hline
\end{tabular}

Key: $\operatorname{TrC}=$ total transaction costs

Source: Brown, Potoski (2002), adjustments Pavel (2005).

When deciding between internal and external production, a municipality should compare the contributions of external provision with transaction costs. Therefore, it is necessary to avoid contracting in case of services, where high transaction costs can be expected. It is illustrated in the above table where the services in quadrant (A) are the most suitable for contracting. Conversely, the services in quadrant (D) are not suitable for contracting and their direct production by the public sector seems to be a more effective solution. The remaining two quadrants can be contracted, although this must be done either by appropriate negotiation strategies or completed by some kind of regulation. A specific option could be making use of various hybrid models, which enable the elimination of possible opportunistic behaviour thanks to the maintenance of a certain level of direct administrative control.

\section{Formulation of Hypotheses}

The above model, which we will continue to call the Brown-Potoski model, demonstrates that the suitability of a service for its external provision decreases together with an increase of the specificity of assets necessary for its production and with an increase in difficulties at measuring of its output. Based on this interpretation, we can formulate several hypotheses, which were subsequently tested on empirical data from the Czech and Slovak Republics.

- HP1: The probability of selecting an internal service provider increases alongside with an increase in the specificity of assets necessary for the service provision.

- HP2: The probability of selecting an external service provider increases together with an increase in the measurability of its output.

- HP3: Municipalities with a higher number of citizens use external production more than smaller municipalities.

The first two hypotheses are directly based on the logic of the Brown-Potoski model and reflect the expected directly proportionate relationship between the measurability 
of individual services and their suitability for external provision, or the conversely proportionate relationship between the specificity of investments and suitability for external service provision. The third hypothesis is complementary and it is based on the assumption that the provision of services in municipalities with a higher number of inhabitants constitutes, for private companies, a substantially more interesting remuneration opportunity than in the case of small municipalities. Here, we can expect bigger competition with stronger consequences for the final price. Bigger municipalities will thus be able to choose from a higher number of suppliers, which will not only have positive effects on the price, but it will also decrease the possibility of origination of a monopolistic dependence. Therefore, we can expect a higher probability that external way of provision will be chosen in this case. As Brown, Potoski (2005) state, that relates especially to the services with high asset specificity.

On the other hand, it is necessary to mention, that there are arguments against the last hypothesis as well. The main of them is that the small municipalities are very limited in their decision making. The problem is very high fixed costs connected with internal production of public services which cannot be covered by the small budgets. Therefore the small municipalities could be predetermined to use external production.

\section{Research Methodology}

\subsection{Collection of Data on the Structure of Securing Services at Municipal Level}

If we want to test the validity of the Brown-Potoski model in the conditions of the Czech and Slovak Republics, it is necessary to know the structure of securing service provision at the municipal level. In order to determine this, research made by subsidiaries of Transparency International in the Czech and Slovak Republics in 2005-2006 was used, where a selected sample of municipalities was asked about the securing of a specific group of services. It concerned the following: cleaning and maintaining of communications, collection and disposal of municipal waste, cleaning of waste waters, maintenance and operation of public lighting, care of municipality's environment (above all, of the parks and such like) and administration of cemeteries.

The research was made by means of a questionnaire whilst municipalities could choose one of the following options to the question of how municipal services were provided:

- Directly (either within the municipal office or by a budgetary allowance organisation);

- By a commercial company (joint-stock company or limited liability company) with the municipality's majority ownership interest;

- By purchase from a private supplier.

The sample's structure is shown in the table below. 
Table 2

Structure of a Sample of Municipalities in the Czech and Slovak Republics

\begin{tabular}{|l|c|c|c|c|}
\hline & \multicolumn{3}{|c|}{ Size category (number of citizens) } & \multirow{2}{*}{ Total } \\
\cline { 2 - 5 } & $\begin{array}{c}\text { Less than } \\
\text { 5 thousand }\end{array}$ & $\begin{array}{c}\text { Between 5 thousand (incl.) } \\
\text { and 20 thousand }\end{array}$ & $\begin{array}{c}\text { Over 20 thousand } \\
\text { (including) }\end{array}$ & \\
\hline Czech Republic & 33 & 26 & 31 & 100 \\
\hline Slovak Republic & 41 & 35 & 24 & 100 \\
\hline
\end{tabular}

Source: own calculations.

Since from the viewpoint of the municipalities' size, the final structure of the selected group did not correspond to the structure of the basic group (municipalities of the Czech and Slovak Republics), it was necessary to make a weighting for the individual calculations. For these purposes, three categories of municipality size were considered: less than 5 thousand citizens, between 5 thousand (including) and 20 thousand citizens and over 20 thousand citizens (including). Basic statistical characteristics (average, decisive departure, etc.) were calculated and subsequently, partial figures were weighted.

Weighting of partial figures was made in two ways:

a) according to the number of citizens,

b) according to the volume of spent funds.

In the first case, the final results show the number of individual solutions from the viewpoint of the number of citizens. However, for a more detailed analysis it was necessary to make also a calculation according to the volume of spent funds. In this case, the partial characteristics of individual size categories were not weighted by proportional representation of the given category in the basic group, but rather by its proportional share in the volume of the total funds spent for the provision of a given service.

\subsection{Evaluation of the Relevant Features of Ordered Services}

In order to evaluate the relevant features of ordered services, we used the method of pair comparison. In the first matrix, the measurability of a given service was compared. If it is easier to measure the service stated in the line than the service in the column, the number one is stated in the point of their intersection. If this relationship is reversed, zero can be found in the point of their intersection. A high number of points means an easy measurability of the service, whilst zero points constitutes a difficult measurability.

The second matrix, which focuses on comparing asset specificity, can be interpreted similarly. If the service stated in the line requires investments, which are more specific than in the case of the service in the column, number one is stated. Otherwise, zero is stated. The most specific investments must be made for the provision of the service with the highest number of points. 
Table 3

Comparison of Monitored Services from the Viewpoint of Measurability of Output

\begin{tabular}{|l|c|c|c|c|c|c|}
\hline & $\begin{array}{c}\text { Maintenance } \\
\text { of communi- } \\
\text { cations }\end{array}$ & $\begin{array}{c}\text { Collection } \\
\text { and disposal } \\
\text { of municipal } \\
\text { waste }\end{array}$ & $\begin{array}{c}\text { Public } \\
\text { lighting }\end{array}$ & $\begin{array}{c}\text { Care of } \\
\text { municipality's } \\
\text { image }\end{array}$ & $\begin{array}{c}\text { Adminis- } \\
\text { tration of } \\
\text { cemeteries }\end{array}$ & Total \\
\hline $\begin{array}{l}\text { Maintenance } \\
\text { of communications }\end{array}$ & $\mathrm{x}$ & 0 & 0 & 1 & 1 & $\mathbf{2}$ \\
\hline $\begin{array}{l}\text { Collection and } \\
\text { disposal of } \\
\text { municipal waste }\end{array}$ & 1 & $\mathrm{x}$ & 1 & 1 & 1 & $\mathbf{4}$ \\
\hline Public lighting & 1 & 0 & $\mathrm{x}$ & 1 & 1 & $\mathbf{3}$ \\
\hline $\begin{array}{l}\text { Care } \\
\text { of municipality's } \\
\text { image }\end{array}$ & 0 & 0 & 0 & $\mathrm{x}$ & 0 & $\mathbf{0}$ \\
\hline $\begin{array}{l}\text { Administration } \\
\text { of cemeteries }\end{array}$ & 0 & 0 & 0 & 1 & $\mathrm{X}$ & $\mathbf{1}$ \\
\hline
\end{tabular}

Source: own calculations.

Table 4

Comparison of Monitored Services from the Viewpoint of Asset Specificity

\begin{tabular}{|l|c|c|c|c|c|c|}
\hline & $\begin{array}{c}\text { Maintenance } \\
\text { of communi- } \\
\text { cations }\end{array}$ & $\begin{array}{c}\text { Collection } \\
\text { and } \\
\text { disposal } \\
\text { of waste }\end{array}$ & $\begin{array}{c}\text { Public } \\
\text { lighting }\end{array}$ & $\begin{array}{c}\text { Care of } \\
\text { municipality's } \\
\text { image }\end{array}$ & $\begin{array}{c}\text { Adminis- } \\
\text { tration of } \\
\text { cemeteries }\end{array}$ & Total \\
\hline $\begin{array}{l}\text { Maintenance } \\
\text { of communications }\end{array}$ & $\mathrm{x}$ & 0 & 0 & 1 & 1 & $\mathbf{2}$ \\
\hline $\begin{array}{l}\text { Collection and } \\
\text { disposal of waste }\end{array}$ & 1 & $\mathrm{x}$ & 1 & 1 & 1 & $\mathbf{4}$ \\
\hline Public lighting & 1 & 0 & $\mathrm{x}$ & 1 & 1 & $\mathbf{3}$ \\
\hline $\begin{array}{l}\text { Care of } \\
\text { municipality's image }\end{array}$ & 0 & 0 & 0 & $\mathrm{x}$ & 1 & $\mathbf{1}$ \\
\hline $\begin{array}{l}\text { Administration } \\
\text { of cemeteries }\end{array}$ & 0 & 0 & 0 & 0 & $\mathrm{X}$ & $\mathbf{0}$ \\
\hline
\end{tabular}

Source: own calculations.

Based on the achieved point evaluation, it is possible to order the services according to both monitored features. The next table shows a comparison of the results achieved by the method of pair comparison with the results achieved, based on research by Sičáková-Beblavá, Beblavý (2007). This evaluated the measurability of services and asset specificity by means of 15 interviews with municipality mayors, heads of municipal offices and directors of financial departments, i.e. employees who directly participate in the service provision decision-making process. The interviews focused on expressions of their opinions on asset specificity and the measura- 
bility of services, while the scale used was the same as found in the Brown - Potoski model (2003). ${ }^{4}$

The results of both approaches are almost identical. Only the order of the maintenance of communications and the care of municipality's image changes in the case of measurability, whilst the public lighting is placed differently, in the case of the asset specificity. According to the results of Sičáková-Beblavá, Beblavý (2007), this service does not have high asset specificity, while according to the method of pair comparison it does. The reason for such a difference may be a different understanding of this service's production. In the case of the mere maintenance of an existing installation, the specificity of investment is quite low, while in the case that the provider would also have to purchase and install the respective device, specificity would increase considerably.

Table 5

Comparison of Results of Own Analysis of Relevant Features of Ordered Services and Results, according to Sičáková-Beblavá, Beblavý (2007)

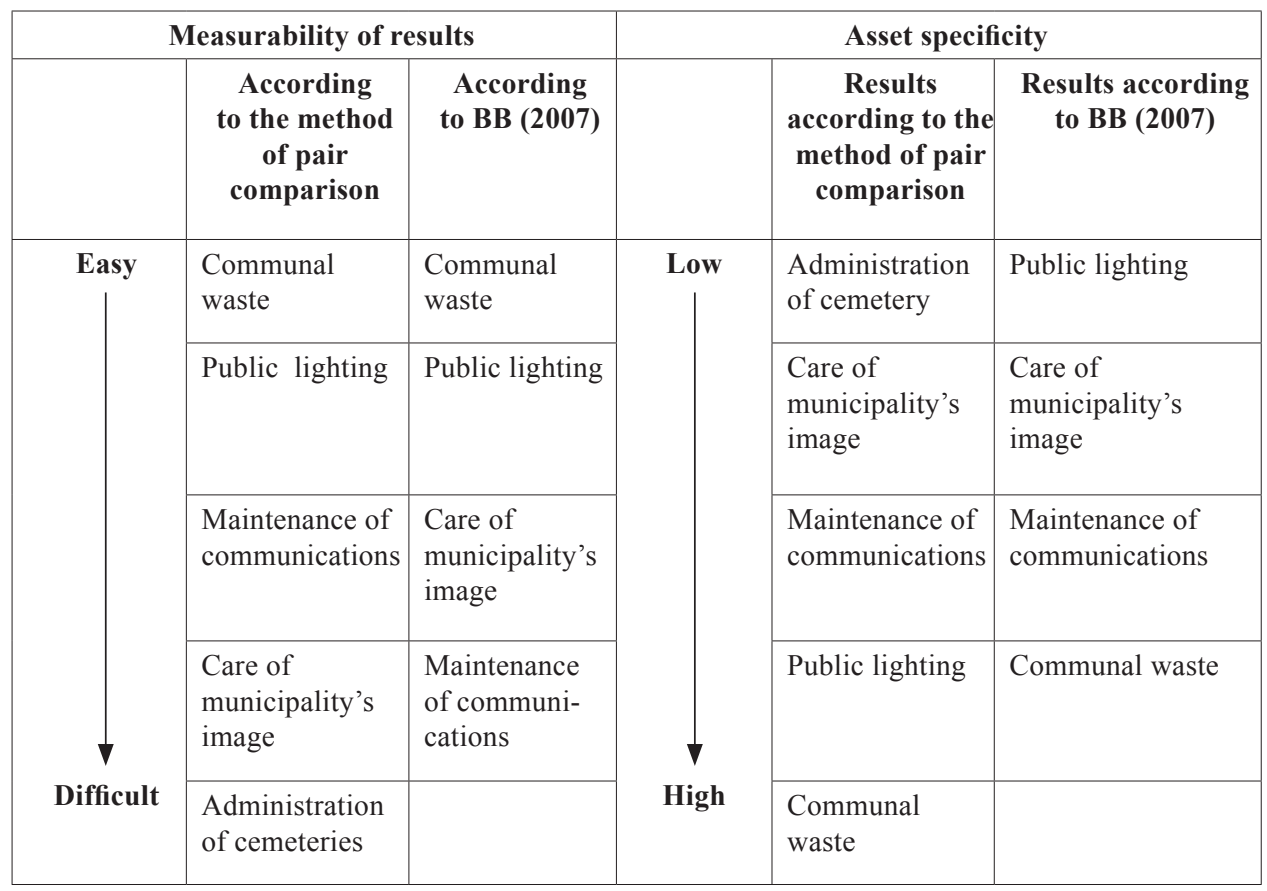

Note: Sičáková-Beblavá, Beblavý (2007) do not deal with the administration of cemeteries.

Source: Sičáková-Beblavá, Beblavý (2007), own calculations.

4 The concept of measuring the specificity of investments and measurability of output was borrowed from the Brown - Potoski model (2003). The determined results were very similar. 


\section{Verification of Validity of the Brown-Potoski Model}

It follows from the Brown-Potoski model that a relationship should exist between the features of a required service and the selected method of its securing. Internal production should be preferred in case of those services which have a low measurability of output and a high specificity of investment. Conversely, external contracting should be more frequent in the case of more easily measurable services with little demands on specific investments. This chapter focuses on the verification of this prerequisite upon data achieved by research carried out in the Czech and Slovak Republics.

The next table orders the monitored services in the left column according to the measurability in output and in the right column according to the specificity of investment, which stems from the results of analysis based on a pair comparison. The neighbouring columns show the share of internal production in both countries. For the needs of this research, internal service provision was deemed as provision of the service directly by employees of the municipal office (or municipal authority), and then by municipal budgetary organisation, municipal allowance organisation and by a commercial company owned by the municipality in the extent of $100 \%$, provided that such a company obtained the order outside the scope of the Act on Public Orders. ${ }^{5}$ All other alternatives were considered as external service provision. If the prerequisites of the Brown-Potoski model applied, it would mean that in both cases, the share of internal production would have to increase.

Table 6

Relationship between the Measurability of Outputs and Specificity of Investment and the Share of Internal Production

\begin{tabular}{|c|c|c|c|c|c|c|c|}
\hline \multicolumn{4}{|c|}{ Measurability of outputs } & \multicolumn{4}{|c|}{ Asset specificity } \\
\hline & \multirow{2}{*}{$\begin{array}{l}\text { According to the } \\
\text { method of pair } \\
\text { comparison }\end{array}$} & \multicolumn{2}{|c|}{$\begin{array}{c}\text { Share of internal } \\
\text { production }(\%)\end{array}$} & & \multirow{2}{*}{$\begin{array}{l}\text { According to the } \\
\text { method of pair } \\
\text { comparison }\end{array}$} & \multicolumn{2}{|c|}{$\begin{array}{l}\text { Share of internal } \\
\text { production }(\%)\end{array}$} \\
\hline & & CR & SR & & & CR & SR \\
\hline \multirow[t]{3}{*}{ Easy } & Communal waste & 24.6 & 26.9 & \multirow[t]{3}{*}{ Low } & $\begin{array}{l}\text { Administration } \\
\text { of cemeteries }\end{array}$ & 71.9 & 91.5 \\
\hline & Public lighting & 50.9 & 71.7 & & $\begin{array}{l}\text { Care of munici- } \\
\text { pality's image }\end{array}$ & 85.7 & 89.5 \\
\hline & $\begin{array}{l}\text { Maintenance of } \\
\text { communications }\end{array}$ & 63.0 & 70.5 & & $\begin{array}{l}\text { Maintenance of } \\
\text { communications }\end{array}$ & 63.0 & 70.5 \\
\hline \multirow[t]{2}{*}{$\begin{array}{c}\nabla \\
\text { Difficult }\end{array}$} & $\begin{array}{l}\text { Care of munici- } \\
\text { pality's image }\end{array}$ & 85.7 & 89.5 & \multirow[t]{2}{*}{$\begin{array}{c}\nabla \\
\text { High }\end{array}$} & Public lighting & 50.9 & 71.7 \\
\hline & $\begin{array}{l}\text { Administration of } \\
\text { cemeteries }\end{array}$ & 71.9 & 91.5 & & Communal waste & 24.6 & 26.9 \\
\hline
\end{tabular}

Source: own calculations.

5 Placing of commercial companies fully owned by a municipality into the "in-house" category is not unambiguous. According to ESD decisions other criteria must be fulfilled for such a categorisation. However, for the purposes of this analysis, we will stem from the above categorisation and consider companies fully owned by municipalities as "quasi in-house", within the framework of the "in-house" category. For more details on various forms of delivery and their use in transition countries see Beblavý (2002). 
The reversely proportionate relationship between the measurability of outputs and the share of internal production is confirmed in both countries, which is parallel with the conclusions of the Brown-Potoski model. On the other hand, the results determined with respect to asset specificity, not only do not confirm the model's conclusions. On the contrary, they indicate a divergent dependence: the share of internal production decreases together with an increase of asset specificity. Therefore, it seems that municipalities do not take into account the possibility of origination of a monopolistic dependence and choose external producers.

The reason why municipalities ignore this danger is probably the relationship between the specificity of investments and their price. In other words, specific investments are more expensive than non-specific investments. With regard to the limited budgetary means, municipalities are not capable of covering such investments and so they are forced to find a partner from the private sector with sufficient capital. This explanation is also confirmed by the fact that in the case of services with high specificity, external producers are preferred, above all, by small municipalities with very limited resources.

Chart 1

Percentage Share of External Provision of Services in Individual Sized Categories of Municipalities in the Czech Republic

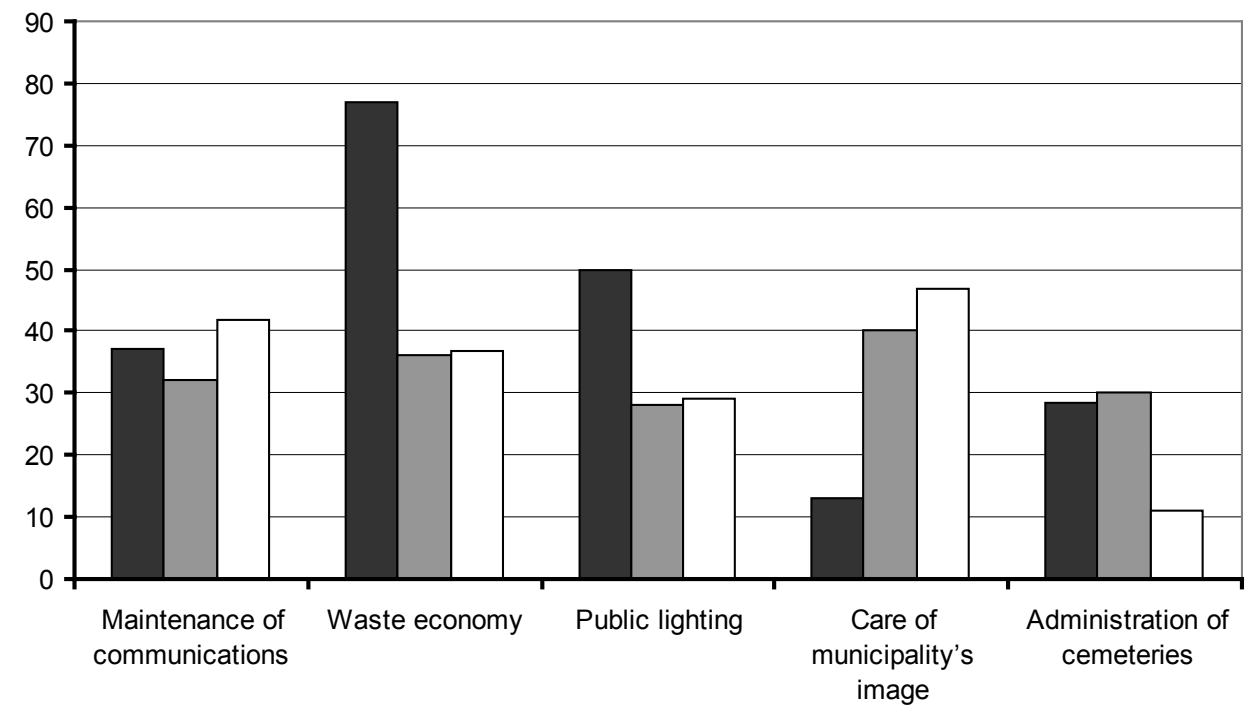

$\square$ up to 5 thousand $\square$ between 5 (incl.) and 20 thousand $\square$ over 20 thousand (incl.)

Source: own calculations. 
Chart 2

Percentage Share of External Provision of Services in Individual Sized Categories of Municipalities in the Slovak Republic

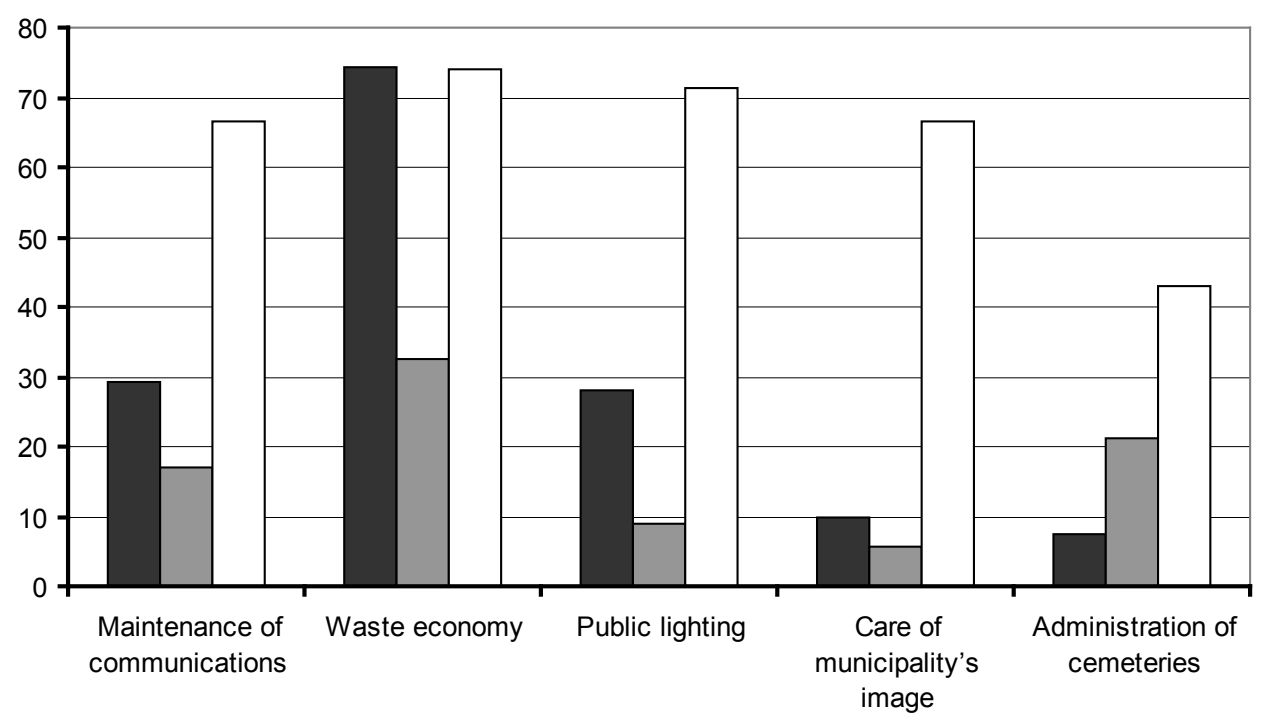

$\square$ up to 5 thousand $\square$ between 5 (incl.) and 20 thousand $\square$ over 20 thousand (incl.)

Source: own calculation.

Alongside the relevant features, the potential share of competition also affects the suitability for external production, as indicated in the hypothesis No. 3. The following two charts demonstrate the percentage of external securing of selected services in three sizes of population categories. It results from the presented data that a positive relationship between municipality size and the share of external provision cannot be identified in the case of all monitored services. In both countries it is, above all, the waste economy, where dependence is divergent: small municipalities prefer external contracts, while big municipalities prefer internal contracts. Again, an explanation can be found in the specificity of investments or their financial demands. Big municipalities already have at their disposal enough resources to enable them to chose the "in-house" model and avoid potential monopolistic dependence.

Based on the presented data, we can observe that a positive relationship between municipality size and share of external production can be unequivocally identified in Slovakia. Here it applies to all monitored services, except for the waste economy. Conversely, this does not apply in the Czech Republic.

\section{Conclusion}

Testing of the Brown-Potoski model in the conditions of the Czech and Slovak Republics showed only its partial validity. While the relationship between the measurability of a required service and its suitability for external provision was 
demonstrated, the relationship between the specificity of investments and suitability for external provision was not. The reason is most probably the already mentioned financial demands of the initial investment, which is, especially in the case of small municipalities, beyond their budgetary means.

The presented results were thus different from other studies which have dealt with the testing of the Brown-Potoski model. In the USA, these were, above all, the works of the model's authors (Brown, Potoski, 2002) and in Slovakia it was the work of SičákováBeblavá and Beblavý (2007). In both cases, the applicability of the model was confirmed.

How can we explain the reasons of the model's partial invalidity in the Czech and Slovak Republics? One of them is a difference in the structure of municipalities. The Czech and Slovak Republics have a high number of small municipalities (the number of their citizens often does not exceed 300) that have very little budgetary means, which considerably affects their decision-making. This is an important difference compared to the structure of municipalities in the USA.

The second reason for the limited validity of the model can be found in its bases. Its construction is based on an assumption that municipalities decide on the way of production on the basis of economic criteria. In other words, their objective is to minimise the costs of provision of a given service in a long-term period, while taking into account transaction costs. The situation in the Slovak and Czech Republics, which still suffer from insufficient establishment of basic political institutions on the level of political representation, does not meet this prerequisite in most municipalities. As can be seen from the results of some partial research, municipal representatives rarely take into account the economic criteria, when deciding on the process of production. It is caused by two types of factors. The first one can be deemed objective. For example, the limited declarative ability of the present accounting system in the public sector or insufficiently developed offers. The second type of factors can be deemed subjective, and they can include for example ideological bases of decision-making or phenomena like corruption or cronyism (Beblavý, 2007).

Respecting the principles defined in the Brown-Potoski model allows rational decision-making concerning the manner of service provision at the municipal level. In order to meet this objective within the conditions of the Czech and Slovak Republics, it is probably necessary to reopen the question of the rationality of the existence of a high number of very small municipalities. It is further needed to make a complex reform of the public sector's accounting, above all the transfer to the accrual basis accounting and implementation of the concept of cost centres. This will secure not only the provision of relevant and meaningful basic documents to municipal representatives for their future decision-making, but it will also increase the transparency of the system and thus decrease the probability of corruption and cronyism. It will thus result in an increased effectiveness of public expenditure, as well as overall economic effectiveness.

\section{References:}

Audit Commission (1995), Making Markets: A Review of the Audits of the Client Role for Contracted Services. London : HMSO.

Bajari, P., Tadelis, S. (2001), "Incentives versus Transaction Costs: A Theory of Procuremet Contracts." Rand Journal of Economics, 2001, 32(3), pp. 387-407. ISSN 0741-6261.

Beblavý, M. (2002), “ Understanding the Waves Of Agencification And the Governance Problems They 
Have Raised In Central And Eastern European Countries." In OECD Journal on Budgeting, Vol. 2, No. 1, Paris, 2002.

Beblavý, M. (2007), "Costs of Corrution and Potencial Remedies from an Economic Point of View." Ekonomický časopis, 55(7), 2007.

Brown, T. L., Potoski, M. (2002), "The Influence of Transaction Costs on Municipal Government Choices about Alternative Modes of Service Provision." Working Paper. Bloomington : Indiana University.

Brown, T. L., Potoski, M. (2003), "Transaction Costs and Institutional Explanations for Government Service Production Decisions." Journal of Public Administration Research and Theory, 2003, 13(4), pp. 441-468. ISSN 1053-1858.

Brown, T. L., Potoski, M. (2005). "Transaction Costs and Contracting. The Practitioner Perspective." Public Performance and Management Review. 2005, 28(3), pp. 326-351.

Cullis, J. G., Jones, P. R. (1987), Microeconomics and the Public Economy : A Defence of Leviathan. Oxford: Bash Backwell. ISBN 063115552X.

Domberger, S., Rimmer, S. (1994), "Competitive Tendering and Contracting in the Public Sector: A Survey." International Journal of the Economics of Business, 1994, vol. 1, pp. 439-53. ISSN 1357-1516.

Goméz-lbáňez, J. A. (2003), Regulating Infrastructure. Monopoly, Contracts and Discretion. Harvard University Press. ISBN 978-0674022386.

Keating, J., Jr. (1990), "Public over Private: Monitoring the Performance of Privately Operated Prisons and Jails." In Macdonald, D., ed., Public Prisons and the Public Interest. New Brunswick, New Jersey: Rutgers University Press. ISBN 978-0813515748.

Kerr, A., Radford, M. (1995), "CCT challenged.” New Economy, 1995, vol. 2, pp. 36-41. ISSN 1070-3535.

Medved', J., Nemec, J., Orviská, M., Zimková, E. (2005). Public Finance. Bratislava: SPRINT. ISBN 80-89085-32-6.

Nemec, J. (2002), "Contractual Securing of Public Services: Theoretical Bases and Practice in the Slovak Republic." Economic Journal, 2002, 50(6), pp. 9-11. ISSN 0013-3035.

Nemec, J., Meričková, B., Vítek, L. (2004), "Contacting-out on Local Government Level. Transitional Economies: Theory and Selected Evidence from Czech and Slovak Republic." In The Eighth International Research Symposium on Public Management, Budapest, 2004.

Oates, W. E. (1977), The Political Economy of Fiscal Federalism. Lexington Books. ISBN 978-1856288484.

OECD (2002), Competition and Efficiency in Publicly Funded Services. Paris: OECD Economic Studies, No.35, 2002/2.

OECD (2006), Roundtable on Concessions. DAF/COMP/GF (2006)2.

Ochrana, F. (2003), Public Choice and Public Expenditure Management. Prague: Ekopress. ISBN 80-86119-71-8.

Ochrana, F. (2007), Public Services - their Delivering, Purchasing and Evaluation. Prague : Ekopress. ISBN 978-80-86929-31-6.

O‘Looney, J. A. (1998), Outsourcing State and Local Government Services. New York: Quorum Books. ISBN 1-56720-169-5.

Pavel, J. (2005), “PPP Projects in the Czech Republic-a Chance or Risk?" Study. Prague: Transparency International Czech Republic.

Savas, E. S. (1987), Privatisation: The Key to Better Government. Chatham: Chatham House. ISBN 0934540586.

Sičáková-Beblavá, E., Beblavý, M. (2007), "Factors Influencing Decisions on Services Provision in Major Slovak Cities." Politická ekonomie, 2007, 55(2), pp. 245-262. ISSN 0032-3233.

Williamson, O. (1981), "The Economics of Organization: The Transaction Cost Approach." The American Journal of Sociology, 1981, 87(3), pp. 548-577. ISSN 0002-9602.

Williamson, O. (1991), "Comparative Economic Organization: The Analysis of Discrete Structural Alternatives." Administrative Science Quarterly, 1991, 36(2), pp. 269-296. ISSN 1087-0091. 